\title{
Towards redeeming marriage custom from 'triangular captivity': The missional dilemma of the Methodist Church in Zimbabwe
}

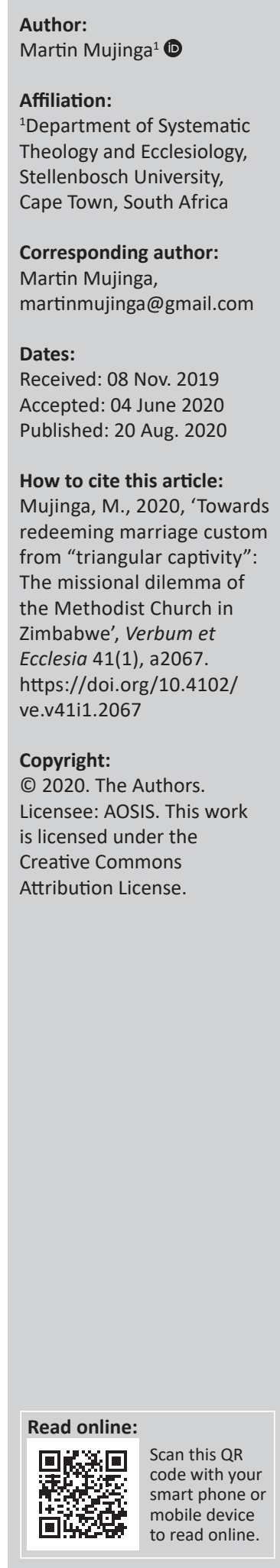

\begin{abstract}
Marriage in the Methodist Church in Zimbabwe (MCZ) is under siege. This scenario was bequeathed by the British imperialists. This siege is evident because the ecclesiastical theology of marriage in the MCZ is fastened on both African culture and the civil order. Firstly, marriage is anchored on African culture because the MCZ is an African church and it grows its mission using African epistemology. Secondly, marriage in the MCZ is affixed on civil authority because adult membership in the the MCZ is defined by being 'properly married' for those who have spouses. The triangular net is evident because marriage starts and proceeds culturally, the government legalises marriages and the MCZ uses marriage certificates to grow its membership, whilst the clergy solemnise marriages as government agents using the civil Marriage Act Chapter 5:11. The aim of this article was to investigate how the MCZ's mission is informed by both African culture and civil order given that it regards marriage as the canon of adult membership, blousing of women and badging of men, participation in the sacrament of Holy Communion, confirmation into full membership, leadership positions, accredited as local preachers and acceptance into ministry. In responding to this aim, the article uses a qualitative research method to interrogate the MCZ policy books and minutes of conferences that address the theology of marriage. The research will conclude by challenging the MCZ to come up with a theology of marriage that unties itself from the cultural and civil net of this rite to interpret its ecclesial mission.

Intradisciplinary and/or interdisciplinary implications: This article is interdisciplinary in the sense that it addresses the issues of ecclesiology, missiology, theology, African culture, gender, church polity and the power of civil authority. The research calls the MCZ to define its marriage theology not contaminated by civil ideologies and African philosophy.
\end{abstract}

Keywords: redeeming; marriage; triangular captivity; missional dilemma; Methodist Church; Zimbabwe.

\section{Introduction}

Marriage is God ordained, culturally oriented and legally bound. Such is the triangular relationship of this rite in the Methodist Church in Zimbabwe (MCZ). In this triangular relationship, the MCZ has a dilemma given that it is either culture or the civil authority that influences its missional identity. The church has an unexplained position as to what it regards as the criteria for adult membership. Is it marriage, wedding, love or the MCZ theology? The MCZ experiences a situation where marriage rite starts and proceeds culturally; the government intervenes at the point of the solemnisation of marriage for those who decide to take this route and when the marriage is being cancelled. Moreover, the MCZ recommends its ordained clergy to the government to be examined, scrutinised and appointed as Marriage Officers. This process makes the clergy civil agents of Zimbabwean government presiding over 'civil marriages' (see Marriage Act 5:11). This article seeks to answer the question, 'at what point does a marriage become Christian in the MCZ since it is the canon of adult membership, blousing of women and badging of men, adult participation in the Holy Communion sacrament, confirmation into full membership, appointed into leadership positions and acceptance as local preachers and also itinerant ministry'. This question will be answered through a literature study and an interrogation of the MCZ literature on marriage. The findings of this research will challenge the MCZ to separate its mission from the triangular relationship where culture and civil authority define its missional identity.

\section{Definition of key terms}

A lot of literature have been written on marriage from the sociological, theological, cultural and ethical point of view. Recent scholarship has digressed from heterosexual marriage and developed 
an interest in interrogating homosexuality as an ethical, cultural and theological dilemma and also as one of the oldest forms of marriages in Africa in particular (see Gunda 2010, 2015; Mangena 2015; Mapuranga 2015; Taringa 2015; Shoko 2015; West 2016). This article is interested in heterosexual marriage given that it is the MCZ's theological position (MCZ 2011b). Amongst a number of definitions of marriage provided by scholars such as Mawere and Mawere (2010), one from culture, civil and theology has been selected for this research.

Culturally, marriage is considered as a covenant between two families that serve as a structural link of the formerly strange parties. This union is bound by the payment of roora (bride price) to the in-laws (Bourdillion 1998; Holleman 1952; Meekers 1993; Mujinga 2019). In Ndebele, roora is called lobola. Roora is an indemnity to the bride's family for their expense in bringing their daughter (1998). It is also a compensation for losing a productive family member to another family (Shorter 1998). The bride wealth as highlighted by Shorter validates marriages and serves to keep the longevity of marriages. As this article is dealing with the Shona culture, the term roora has been deliberately chosen. The civil understanding of marriage in Zimbabwe is problematic, firstly, because the Zimbabwean Constitution does not provide for the definition but instead gives the conditions and rights for marriage (Mangwana, Mwonzora \& Moyo 2013). Secondly, the first Marriage Act of 1964 and its amendment versions also do not offer a precise definition of marriage but, instead, address issues of how Marriage Officers are designated and revoked, solemnisation process of marriages and publication of banns amongst other legal issues.

Theologically, marriage is defined as the union for one man and one woman bound by God (Richardson \& Bowden 1983). The Methodist Church in Zimbabwe emphasises that marriage is the binding and lifelong character of the marriage vows outlined in the Marriage Service (MCZ 2011b:204). The church also believes that 'Christian marriage is divinely ordained by God' (MCZ 2011b:205). The selected definitions will inform the basis of this article. Not much attention will be given to both the historical and theological developments of Methodism in Zimbabwe because scholars like Banana (1991), Gondongwe (2011), Mujinga (2017) and Zvobgo (1991) have done much justice to this subject.

\section{Methodological considerations}

This research used qualitative research methodology of reviewing the existing literature, also known as literature review research methodology (Snyder 2019). Reviewing the literature is designing a research project where the researcher needs to sample data from the existing literature. This methodology has been chosen based on the hypothesis that building research on and relating it to existing knowledge is the building block of all academic research activities. In this article, the literature review research methodology will help understand how the MCZ's mission is informed by both
African culture and civil authority. There are a number of merits in using the literature review research methodology. Firstly, Webster and Watson (2002) mention that an effective and well-conducted review as a research method creates a firm foundation for advancing knowledge and facilitating theory development. By integrating findings and perspectives from many empirical findings, a literature review research methodology can address research questions with a power that no single study has. Secondly, this methodology also helps to provide an overview of areas in which the research is disparate and interdisciplinary (Webster \& Watson 2002). Thirdly, the literature review research methodology is an excellent way of synthesising research findings to show evidence on a meta-level and to uncover areas in which more research is needed, which is a critical component of creating theoretical frameworks and building conceptual models. In this research, the literature review research methodology endeavours to unpack marriage rite as a complex phenomenon that has posed challenges on the growth of the MCZ mission.

In this article, cited methodology has been selected because it offers an opportunity to observe, interpret and interrogate several sources related to the study. The research targeted literature from the MCZ, African culture and the Marriage Act. Particular attention was given to the MCZ's policy documents like the Deed of Church Order and Standing Orders, Ruwadzano/Manyano and Men's Christian Union (MCU) Constitutions and minutes of conferences. Ruwadzano is a Shona term that means fellowship and Manyano is the equivalent term. In the MCZ, the two terms are used as one word Ruwadzano/Manyano to refer to the uniformed women's fellowship (Mujinga 2017:131), whilst MCU is a uniformed men's fellowship or Ruwadzano RwaVarume or Umanyano LwaMadoda in Mangena and Ndlovu (2013:473). Men's Christian Union is the common term used in this organisation. The contents of these constitutions will help to challenge the MCZ to redefine its theology in the context of cultural and civil triangulation. By using the phrase 'triangular captivity', the research assumes that the marriage rite in the MCZ is interwoven with culture, civil authority and the MCZ theology which cannot be easily disentangled. In this triangulation, the MCZ theology is suppressed by culture and civil interpretation of marriage, thereby making the two speak with a louder voice in the MCZ mission.

\section{Marriage amongst the Shona people in Zimbabwe}

Zimbabwe is a multi-religious, multilingual and multicultural country. This article will briefly highlight the understanding of marriage amongst Shona people because the subject has been oversubscribed (see Holleman 1952; Mawere \& Mawere 2010; Mwandayi 2017; Obbo 1980). Shona people are the majority in Zimbabwe, comprising the Zezuru, Ndau, Manyika, Korekore and Karanga ethnic groups (Doke 2005; Mwandayi 2017), thereby making them the majority of the MCZ membership. Marriage amongst Africans in general and Shona people in particular is polygamous. Amongst the 
Shona people, there were different types of marriages, some of which are still considered culturally right and others are now viewed as abuse of women's rights.

The first type of marriage is kukumbira (requesting). This type of marriage is regarded as the most descent method of union amongst the Shona people (Bourdillion 1998; Holleman 1952; Kileff \& Kileff 1970; Mawere \& Mawere 2010; Mujinga 2019). Kukumbira marriage is also the most respected and most encouraged form of marriage even by the MCZ. However, the marriage is more respected when the cultural process has been blended by the civil procedure of the solemnisation of the marriage either in the civil court or, more favourably, in the church by the clergy.

The second type is kutizira or kutiziswa (eloping). Kutizira is when the woman initiates the move, whilst kutizisa is when the man initiates the process; however, both words mean anticipating marriage. This type of marriage is not encouraged amongst young boys and girls. Methodist Church in Zimbabwe accepts anyone who elopes to be a full member of the church on two conditions. Firstly, that their marriage is solemnised through the church or civil court procedure. Secondly, that the individuals, women in particular, are given a longer period of being assessed. Men are seldom processed as full members when they do not have a civil marriage certificate.

The third form of marriage is kuzvarira lit. 'Giving birth for'. This marriage implied that a poor family that has difficulties to maintain itself gives a very young girl to a family who would provide roora, in advance which enables them to survive. In this type of marriage, if the girl was mature, she would go to the family she had been married into without her consent. If the father of that family is too old, the girl was given to a son or nephew. In the event that the girl runs away, the family, to which the girl was married, would claim their roora back (Mawere \& Mawere 2010). Holleman (1952:115121) calls it 'a credit marriage'. This type of marriage is now forbidden by the Constitution of Zimbabwe (ZIMLII 2013: $28,47)$ as it states that 'no marriage should be entered into without the free and full consent of the intending spouse'.

The fourth type is chigara mapfiwa lit. 'To inherit the fireplace' or substitution marriage. Chigara mapfihwa refers to how a relative of the deceased wife, mostly her brother's daughter who is not married or her young sister, is given to the surviving husband to take care of the property of the deceased wife. The marriage implied that cooking for the husband would continue and is managed by the same family where the first wife came from. The decision to give the existing man the wife could be the wish of the deceased wife herself. The deceased wife will be considerate of her children, and the best person to take care of them is her relative instead of other wife that the husband would decide to marry.

In fifth form of marriage is kugara or kugarwa nhaka (levirate) or succession marriage. Levirate is a type of marriage in which the brother of a deceased man is obliged to marry his brother's widow. The term levirate is a derivative of the Latin word levir, meaning husband's brother (Holleman 1952). This practice was also common amongst the Shona people. Succession marriage meant that a woman was expected to be looked after by a brother (same father or same mother; or same father or different mothers) or the cousin of the deceased. This type of marriage was abandoned because of the prevalence of HIV and AIDS and other reasons like the perpetual abuse of some widows.

The sixth type of marriage was kutemaugariri or service marriage. This is a marriage whereby a poor man, who is not able to pay roora, will live and work at the wife's homestead for a period of time, providing his labour in lieu of paying roora. A typical example of this type of marriage is the biblical story of Jacob when he married Leah and Rachael and also obtained his wealth from his father-in-law Laban. The bible says:

So Jacob served seven years to get Rachel, but they seemed like only a few days to him because of his love for her ... But when evening came, Laban took his daughter Leah and brought her to Jacob, and Jacob made love to her ... When morning came, there was Leah! So Jacob said to Laban, 'What is this you have done to me? I served you for Rachel, didn't I? Why have you deceived me?' ... Finish this daughter's bridal week; then we will give you the younger one also, in return for another seven years of work ... And he worked for Laban another seven years. (Gn 29:20-28 [NIV])

The Shona culture inherited this Jewish culture. However, this type of marriage has since disappeared because of modernisation.

The seventh type of marriage practised by the Shona people is musengabere lit. 'To carry a hyena and run away with it'. This marriage describes how a man marries a girl after raping her. The man will be in love with a girl with the intentions of either marrying her or to abuse her sexually. The man kidnaps the girl and takes her to his place. The following day he will order the girl to leave. The girl finds herself stranded. She cannot go back to her parents' place because the parents cannot account for where she slept the previous night. Thus, she has no other choice but to stay with the man who abused her. This is a forced marriage and the girls' family charges a very high amount of roora called damage.

The eighth form of marriage is meant to compensate the avenging spirits of a person killed by a relative. The family suspected of killing has to give a daughter to the family whose member was killed. That woman would be married in the name of ngozi (avenging spirits). Ngozi demands compensation of a person in the form of a virgin girl. The girl is married to a male relative of the deceased, specifically to bear children (Shoko 2007). Shona-speaking people believe that although this marriage can be described as a 'ghost marriage', however, the spirit of the one killed would be happy by such a union. The deceased will, in turn, protect the family from illnesses and other forms of misfortunes (2007). 
Although it is evident from these discussions that some types of marriages were banned by the Zimbabwean Constitution, however, whatever form of cultural marriage that any MCZ member enters into, it is not regarded as worth until it is solemnised either by the civil court or by the church on behalf of the government. The Marriage Certificate should be the evidence of the 'marriage' (see MCU Constitution 2018; Ruwadzano/Manyano Administration Policy and Constitution 2015). Culturally, once roora has been paid, it is considered that one is married and it confirms the right to sex by the new husband (Magesa 1997). Once roora is paid and consequently accepted by the in-laws, and then marriage is deemed to have taken place between the two families. Methodist Church in Zimbabwe is contrary to this point because this marriage is not 'Christian' for as long as there is no civil marriage certificate. The dilemma that the MCZ has is to inculturate biblical forms of marriage blended with African culture to make it a 'Christian marriage'. Roora is a key phenomenon in the African culture, whereas the MCZ has nothing to do whether the son-in-law pays roora or not for as long as he has a marriage certificate, he qualifies to be a member of the church and MCU. To a certain extent, it works to retain fidelity in the marriage institutions and total commitment to each other. Unfortunately, the MCZ's theology of marriage is foreign to this cultural fact and yet grounded in the Eurocentric concept of marriage which is highly civil in nature.

\section{De-culturate to civilise? The missionary approach to marriage in Zimbabwean Christendom}

Christianity in Zimbabwe came into a society where marriages were already in existence. To convert the Shona people, missionaries made a robust denigration of polygamy and all forms of African marriage cultures as heathen and outdated (Gelfand 1968). Zvobgo (1996) stresses that before the coming of the missionaries, marriage in Africa was deeply communal and cultural. However, the missionaries' teaching diverted the African understanding of this rite. They saw polygamy as evil and wife enslavement and roora as another way of commoditisation of women and enslaving them in the rest of their lives. Missionaries did not understand African epistemology and monogamy was used as a criterion to Christian membership. Hatendi (1973:138) stresses that 'polygamy was the norm rather than the exception thereby making the percentage of polygamy very high at the coming of the missionaries'. Amongst the Shona, polygamy was a social solution to social problems like looking after the widow of the deceased brother or to beget children in the name of the brother who died without children. For other men, polygamy was a status symbol, a source of cheap labour and satisfaction of the lust (Hatendi 1973). From this background, it is evident that polygamous custom grew not because there were too many women to marry, but it was a privilege of the powerful rich at the expense of the weak and the poor women in which those days it was not interpreted as abuse but security of the widow.
In spite of whatever reason of polygamy, missionaries could not tolerate anything short of monogamous marriage. Any form of marriage that could not match their standard was discarded. On one hand, the missionaries were right to defend the rights of the poor, and on the other hand, their approach was more disastrous. The major challenge was for the man to dismiss the second wife and her children to remain monogamous and become a Christian. This was a form of abuse on both the divorced wife and the children who would be fatherless because their father decided to be a Christian and yet Christianity embraces the weak. Missionaries had no intention to inculturate Christian faith into African culture. The result was that African marriage customs, rituals and rites had no place in the 'Whiteman's religion' because they imposed their marriage set patterns to the Africans (Banana 1991). Those engaged by African customary marriage could not be accepted as full members of the church. Banana (1991) bemoans that missionaries denounced African marriage completely without a theological understanding of the rite (see also Bhebhe 1979; Bourdillion 1998). Such an approach led to a clash of their mission which was not transplanted into the African reality and African culture which believed in polygamy as an identity of personhood. As Methodism came in a polygamous culture, it is worth pursuing how the discourse of polygamy was handed by the church.

\section{The development of marriage discourse in the Methodist Church in Zimbabwe}

The history of marriage discourse in the Methodist church traces as far back as 1932. The early years of Methodism in Zimbabwe concentrated much on marriage in the formal meetings of the church like Synods which is now called conference since 1977 (see Mujinga 2017). The Synod of 1932 passed a resolution on marriage stipulating that only members who were married according to Christian rites would be accepted as full members and would receive the Holy Communion (Gondongwe 2011:56). African ways of marriage were denigrated as evil. Even old couples with several children were told that they were only cohabiting as long as their marriage was not solemnised by the minister of religion who was representing the civil authority (2011:56). Methodist missionaries emphasised that a Christian man was not allowed to marry a non-Christian woman unless there were exceptional reasons. Roora was initially castigated but with the passage of time, it became recognised as an integral part of the Bantu social custom (2011 56). Nonetheless, as time went by Christian parents were discouraged from charging exorbitant roora and polygamy was condemned. Two issues come out clear from the position of the missionaries: firstly, the missionary ideology forced itself into the nerves of African culture to the extent of prescribing how much to charge on roora. Secondly, Africans were torn between their cultural identity that embrace all and the missionary philosophy that divided all. This situation led to a further, missio-cultural confrontation where missionaries failed to inculturate Christianity into the local culture. Hewitt (2012) defines missio-cultural as the 
dynamic relationship between mission and culture. The intermutually penetration of the nexus between the missionary understanding of marriage and that of the Shona people continuously failed to resonate.

Gondongwe (2011) confirms that by 1940, the issue of 'Christian marriage' was still giving the church authorities some problems. The Wesleyan Methodist Missionary Society in Britain wrote to the Methodist District of Rhodesia (now Zimbabwean Conference) to offer some 'wisdom on the matter'. The letter says in part:

It is quite obvious that the problem of marriage and its subsidiary difficulties have created as much difficulty in Rhodesia as elsewhere in Africa and we sympathize very much with those who have to deal with these problems at first hand... Most certainly the marriage of a Christian man to a nonChristian woman should be forbidden, and any Christian man entering into such marriage should be disciplined... (Gondongwe 2011:57)

More confusing, as one notes from Gondongwe, was the efforts by the Church in Britain to give what it called 'wisdom' to missionaries in Rhodesia to further truncate the Shona from their cultural pride. Evidently, 'Christian marriage' institutions sought to alienate black people from their culture given that marriage in Africa was a matter of religion (2011:58). Manyoba (1991) emphasises that:

[I]n 1939, the Rhodesian Synod declared that those who marry by African customary marriage could not use their husband's names. In 1949, Synod only recognized 'Christian marriage' and it was declared as the entry into membership. This was a clear sign that the church could not tolerate marriage by African custom. (p. 71)

In 1953, Synod further ruled that those people married customarily could not become church leaders. In 1954, Synod also passed a resolution that:

$[W]$ omen married in accordance with customary law could not use the husband's surname even in the church for as long as that marriage was not registered with an officer of the Native Commissioner. (Manyoba 1991:74)

The office of the Native Commissioner, is the one being referred as the civil authority in the article. For Manyoba, this action by the missionaries demonstrated that customary marriage was not proper and relegated to sinful status (1991:74). Such a move caused some prominent members to live the church because they were suffering from a religious schizophrenia of being torn between accepting God who love people regardless of their culture and embracing the missionary culture of monogamy that was discriminatory. The decrease in male membership led the Methodist church to relax on excommunicating polygamist; however, missionaries continue to condemn, criticise and demonise African marriage culture intensively (Bourdillion 1998; Dachs 1973; Hatendi 1973; Zvobgo 1991, 1996).

Although the Methodist church relaxed on polygamy, its organisations of men and women continue holding onto this teaching. In Ruwadzano/Manyano, which is the biggest female organisation in the $\mathrm{MCZ}$, those in polygamous marriages are not allowed to wear the red blouse because they will not have been accepted as full members of the church. The wearing of a red blouse by women in the Methodist church is one of the most prestigious statuses that most women would want to be associated with the theological meaning of the women's uniform has been well articulated by Mujinga:

The black skirt is an acknowledgement of the past sins. The red blouse symbolizes the blood of Jesus that washes away sins. The white collar and hat stands for the new life which is fulfilled in Jesus Christ through the Holy Spirit. The five buttons with one on the belt represent the five wounds of Jesus on the cross. The hat has six panels that symbolise the fruit of the spirit, which is expected to characterise women in this movement namely forgiveness, perseverance, justice, humanity, peace and love. The brim that brings the panels of the hat together symbolises Ruwadzano/Manyano women as the people of prayer for unity in the movement and in the world. The collar symbolises the burden of the cross women have to bear in all times. (2017:131-132)

Ruwadzano/Manyano uniform is worn only by the first wife even without a wedding after a thorough examination and long waiting (Gondongwe 2011:73). Zvobgo has it that:

$[R]$ ules and regulations governing church membership were laid down for the Africans desiring to be members of the Methodist Church. One of the conditions was the solemnization of marriage according to Christian rites serve for those wives whose husband persistently refused to be married by Christian rites. (1996:323)

The term 'Christian rite' in this circumstance did not refer to biblical, but to civil marriage because religion and politics were trading together. In addition, all polygamists were to fulfil the obligation of monogamous marriage, by sending away the other wife or wives. No person could be a member of the Methodist church who did not accept the 'Christian view' of marriage. In severe cases, those who practise elopement marriage were actually expelled from the church (Banana 1991). The qualification of the so-called Christian marriage and yet civil marriage became the standard procedure and criteria for those called into the office of local preaching and those desiring to serve the church as ministers.

All male members and Christian workers were forced to enter into 'Christian marriage' before cohabitation, and all existing 'non-Christian marriage' of members and workers were required to be ratified by 'Christian marriage' within a reasonable time. No 'Christian marriage' was to be performed between Christian and non-Christian partners until its meaning and implications had been explained to and acceptable by both parties (Zvobgo 1991). The missionaries realised that the threat to salvation for Africans was polygamy, which in my view was a fallacy. Missionaries intended to explain to the members that only monogamous marriages were tolerated and acceptable by the church. This view by the Methodist missionaries translates verily to the views of Hatendi (1973) who argues 
that the European churches upgraded the Shona Customary marriage to suit their 'Christian marriages'. The failure by the missionaries to interpolate with the existing marriage cultural systems undermined the foundation upon which the mission of the church amongst locals was supposed to be built on.

From the prevailing discussions, it is evident that MCZ's theology of marriage was defined by the language of the missionaries and the civil authority. However, although the church became autonomous from the British Methodist in 1977 (Gondongwe 2011; Madhiba 2000; Mujinga 2017), the missionary interpretation of marriage found its way into the Constitution and mainstream organisation of the autonomous Methodist. Evidently, the MCZ was satisfied by the Eurocentric place of this rite bequeathed to them. An analysis of the constitutions and policy books of the MCZ is evident that the Eurocentric tendencies dominated the church's marriage theology. Methodist Church in Zimbabwe's theology of marriage remained balanced on civil and cultural interpretations and this posed a number of problems. The first challenge being the lack of a proper definition of marriage by the MCZ as argued earlier. The second challenge is to explore the statement that 'Christian marriage is a life long unity' (MCZ 2011b:204). The question is, at what point does a marriage become Christian? The third challenge is, how do we theologise a legally bound marriage in the civil procedure? The MCZ Service Book states that 'the man/woman, say in the presence of the "authorized person or the Registrar"' (British Methodist Church 1992:E5). The words 'authorized' and 'registrar' tie the role of the MCZ theological interpretation of the marriage custom to civil authorities. This Eurocentric view was transplanted to Africa in general and the MCZ regards marriage governed by civil authority (Marriage Act Chapter 5:11) as its canon for missional standards.

Methodist Church in Zimbabwe realised the impact of these challenges on its missional identity. During the celebration of 30 years of autonomy and 300 years of commemorating Charles Wesley's life in music (1707-2007), the MCZ officially launched Men to Church Programme and Financial Breakthrough Initiatives (MCZ Minutes of Conference 2008). Men to Church Programme was a vigorous campaign to attract men to church. The programme started in 2006 and a bigger number of men came to church. Unfortunately, this male membership drive was challenged by the MCZ's theology of marriage which is Eurocentric, cultural and legally bound. In 2006, the Mission Committee recommended to Conference that ' $\mathrm{MCZ}$ should revisit its position in relation to polygamy in which Hwange District had penetrated through their evangelism efforts to areas where some men were repenting whilst polygamous' (MCZ 2006:13).

Conference agreed to the resolution and mandated a task force to research on the theological interpretation of the issue. More men continued to come to church and this was evidenced by the 2008 statistics that showed a $5 \%$ increment from the previous year (MCZ 2008:85) and yet the MCZ had no theological position to its missional enterprise free from culture and civil interpretation of marriage to accept them as full members. The problems were exacerbated by the contradiction in Church's policy book, the Deed of Church Order and Standing Orders with regard to membership and marriage. On the one hand, the 1997 version of the Deed of Church Order and Standing Orders states that:

The names of those to be received into full membership of the Church must be approved by the Local Leaders Meeting (the local meeting). Proof of marriage where relevant should be obtained. Where no marriage certificate is available, each case should be considered by the Leaders Meeting. The meeting should verify that the marriage is life long, monogamous and has been stable for five years. (1997:111)

On the other hand, the reprinted version of the Deed of Church and Standing Orders of 2011 left the details of the constitution on marriage. It is not clear why the MCZ decided to be inconsistent in its theological position on marriage yet it plays a central role in its missional work. Qualification into full membership of uniformed organisations is enshrined in the men's organisation, the MCU and Ruwadzano/Manyano, the women's fellowship policies.

A literature review of the above policy books shows that for one to be confirmed as a full member of a uniformed organisation requires the acquisition of a Marriage Certificate (MCU Constitution 2018; Ruwadzano/Manyano Policy Book and Constitution 2015). This position leaves the MCZ's missional work conflicting itself, firstly, between the church itself and its organisations. Secondly, its membership is controlled by the in-laws because their consent to a wedding is the position that the MCZ takes. Any full member should have a civil marriage certificate. If the inlaws do not consent to solemnisation of the wedding, the MCZ does not go ahead in confirming such individuals into full membership. For example, during the process of the solemnisation of marriages the clergy officiating the marriage using the MCZ Shona Hymn Book would ask, ndiani anopereka mudzimai uyu kuti asvitse nemurume uyu? ... baba zvimwe nyakuperekedza anozoti; ndini! (2005:42), lit. 'Who is handing over this woman to wed with this man?...'. The father or anyone representing him will say, 'I am the one'. The first challenge that the MCZ has is that without the inlaws, 'Christian marriage' is invalid and in turn the MCZ mission is compromised. Secondly, this part of the liturgy is only found in the vernacular hymnbooks, suggesting that the MCZ inculturated its theology on marriage and attached this Africanisation philosophy to its mission. Thirdly, the clergy during the solemnisation of marriages does not represent the ecclesiastical order, but the civil authority to legally bind the marriage after which the Duplicate Marriage Certificate will be registered with the Ministry of Home Affairs and Cultural Heritage (Marriage Act 5:11).

From the expositions presented above, the triangulation challenge of marriage is an MCZ's dilemma. Firstly, once the son-in-law pays roora culturally, the in-laws allow their daughter to join her husband. The fathers will instruct their sisters to perform the rituals that include handing over the daughter-in-law to her married family through the process of 
kupereka (handing over). Contrastingly, for the Methodist church once the son-in-law accepts his wife before the solemnisation of marriage, it is regarded as anticipating marriage and both the man and the woman will be disciplined. Ngundu (2011) asserts that the church takes it upon itself to count the exact number of months before the birth of the child; if the days do not count to 9 months and the child is not premature, the couple will be disciplined even with a 'Christian marriage'. This position demonstrates that the church will be informed by the civil theology that if one has a Marriage Certificate qualifies to be a Christian and yet this marriage is a western way of excluding Africans from the presence of God.

\section{Challenges of conflicting position on marriage for Methodist Church in Zimbabwe's missional identity}

A review of the MCZ literature on membership shows that marriage defines the missional identity. As argued earlier, the MCZ Constitution does not attach membership to marriage. Rather, it states that 'membership shall be for those who confess Jesus Christ as Lord and Saviour and accept the obligation to serve him in the life of the church and the world' (MCZ 2011b:3). This position is contrary to the uniformed organisations of the MCZ like Ruwadzano/Manyano and MCU. These organisations have become the most popular within the entire $\mathrm{MCZ}$, one of the reasons perhaps being that the uniform itself confers a substantial amount of dignity to women and men (Gondongwe 2011; Mujinga 2017).

On the one hand, the Ruwadzano/Manyano Policy and Constitution (2015) item 3 clearly states that, kuti madzimai vapfeke bhachi dzuku, vanofanira kuve nevaine muchato uzere we Chapter 5:11, uyezve vanofanira kugara sevayedzwa kwegore rose ...nhengo dzisina muchato we Chapter 5:11 dzinofanira kugara kwemakore matatu dzisati dzpfeka. Mudzimai anenge akaroorwa ari mukadzi wechipiri haafaniri kupfeka bhachi reRuwadzano/ Manyano. Lit. 'For women to be bloused, they must have a Marriage Certificate Chapter 5:11. Those without the certificate must wait for three years as On Trials and anyone on polygamous marriage will not be bloused'. Secondly, the Ruwadzano/Manyano Administration Policy and Constitution (2015) also emphasise that, 'during the blousing process, the president (minister's wife) should make sure that members are "properly married"'. Those with 'Christian marriage' may lead the church at different levels as per the church policy enshrined in the church policy, the Deed of Church Order and Standing Orders (MCZ 2011b:9). The policy further states that, 'members with customary marriages maybe bloused but may not be elected into the positions of leadership'. On the other hand, the MCU policy states that, 'any man who chooses to be a full member of the MCU must be married to one wife. A polygamist may attend the MCU meetings but shall not be badged' (MCZ 2018:6).

The Methodist Church in Zimbabwe inherited this Eurocentric culture and applied it in its ecclesiastical life; however, there has always been need to revisit this theology. In 2006, the MCZ Conference agreed to revisit the church's position in relation to polygamy in light of the new believers who were converting as a polygamist. In 2011 MCZ Annual Conference received a recommendation from the Mission Committee which states that, 'given the launch of the Men to Church programme, and the high turnout of men to church, there is need to critically analyse what we call "Christian marriage" against a legal marriage that links to the full membership of the church' (MCZ 2011c:40). In response, Conference resolved that:

The Church should bless monogamous customary marriages in order to do away with the belief that a 'white wedding' is the legitimate marriage. The blessing should be the marriage vows as well as certification. The blessing should have parental consent in order to curtail family conflicts. (MCZ 2011a:88)

In 2011, it was the first time when MCZ was trying to divorce itself from both the civil and cultural attachment to define church membership by marriage. Unfortunately, the contents of the resolution remained a talk and MCZ could not free itself from this triangulation crisis. This point is buttressed by the second part of the resolution which states that, 'the marriage should be blessed at the Magistrate Court to avoid blessing illegal marriages' (MCZ 2011a:88). The resolution faced two challenges. Firstly, the lay members of Conference who on the agenda of each Conference take time to discuss the life of the church on their own, rejected a proposal to discuss polygamous marriage and called it as an 'unChristian marriage' (2011a:88). Secondly, in an attempt to redefine its ecclesiastical marriage theology, the MCZ could not avoid the cultural role of the in-laws and the civil role of the magistrate. The church only dealt with the peripheries of the matter, like condemning 'white wedding' ignoring the fact that, most of the couples tying the knot in civil courts, the women dress in white gowns.

In spite of these challenges, the $2013 \mathrm{MCZ}$ Conference took the debate further to analyse the definition of 'Christian marriage'. A taskforce comprising Bishop Aaron Makiwa, Revd Dr Levee Kadenge, Itai Watinaye, a Legal Practitioner, Revds. Noel Nhariswa and Georgina Juru and a Radio Presenter on Chakafukidza dzimba matenga, a programme that discusses marital life every Tuesday on Radio Zimbabwe and widow to the Methodist minister, Mrs. E. Serima was appointed. The team was grappling with the legal marriage instruments, Marriage Act 5:07 which is potentially polygamous and Marriage Act 5:11 which is serially monogamous and what makes marriage Christian. The taskforce reported that:

Marriage is a social construction based on social and cultural values. Marriage Act 5:11 is the one MCZ acknowledges and it gives legal protection, African marriages are done in the village where the groom pays roora and is accepted as the son in-law. At that stage, one is considered married and there is a union between the in-laws. A white wedding is what MCZ calls 'Christian marriage' and many people are not able to reach this stage for various reasons resulting in losing their membership in the church but according to their families, they are married. (MCZ 2013:A2) 
The taskforce proposed that the MCZ should redefine marriage as:

A union of husband and wife, having been blessed by parents through acceptance of bride price. The union of marriage should be followed by the Church blessings through a Blessing Certificate. Soon after the marriage ritual in the family and the member can take his or her place in the church. The church will therefore teach members on the advantage of making their marriage legal under Marriage Acts 5:11. (MCZ 2013:A2)

\section{The presentation went further to state that:}

MCZ does not accept polygamous marriage, but accepts children from the polygamous marriage and the first wife and not the husband and the other wives. Ruwadzano/Manyano and MCU should do the same, red blouse to the first wife and white blouse to the other wives. To MCU, no jacket should be badged to the polygamous man. (MCZ 2013:88)

Conference agreed to the recommendations.

From the church's policy, the Deed of the Church Order and Standing Orders, the constitutions of the Ruwadzano/ Manyano and the MCU and the conference resolutions of 2006, 2011 and 2013, the MCZ failed to redeem itself from the surrogate Eurocentric understanding of marriage. This is evidenced by the fact that, firstly, the definition of 'Christian marriage' was never convincingly provided; secondly, the stance on excluding the polygamous men was intensified. In 2013, the MCZ made the worst resolution than the missionaries. They declared that only the first wife should be accepted as a full member of the church. Thirdly, culture and civil theology of marriage continued to define the MCZ's position of marriage. These challenges leave one grappling with the stance of the MCZ on marriage in this triangular connection.

The Methodist church embraced Eurocentric theology of marriage. Unfortunately, the move to condemn African marriage did not take into consideration that marriage was culturally oriented. The Methodist Church in Zimbabwe accepted a theology of marriage that was knitted by three contrasting institutions, namely, African culture, civil philosophy and the MCZ theology. This made the Methodist Church to become an impediment to all those married in the African customary way. They could or cannot access full membership of the church and partake of the Holy Communion a sacrament that demanded 'Christian marriage' as a qualification for those unmarried until 2018 when the MCZ Conference changed its Holy Communion theology from qualification to invitation (MCZ 2019:R8). By qualification, the Conference meant that only full members would partake, whilst invitation does not analyse anyone's the membership. In the later position, Holy Communion is viewed as a means of grace unlike in the former where the sacrament is received by status of being a full member.

\section{The Zimbabwean marriage legal frame and how it impacted the Methodist Church in Zimbabwe mission}

The traditional Zimbabwe had a number of marriages that were all recognised as valid by the Shona people as argued earlier. However, the colonisation of Zimbabwe influenced the general understanding of marriage (Bhebhe 1979). The rite was redefined using Eurocentric terms and vocabulary with the aim of mystifying the custom. In the process, some marriage practices were labelled 'civil', whilst others were called 'traditional marriages' assuming that they were outdated (Bourdillion 1998). The Marriage Act of Zimbabwe legalises marriage and divides it into civil marriage, registered customary marriage and unregistered customary marriage (Marriage Act 1983). In the Marriage Act Chapter 5:11, the government is the custodian of marriages represented by Minister of Justice, Legal and Parliamentary Affairs and Cultural Heritage. The magistrates and designated clergy are used as extensions of the government's efforts to legalise the custom and instead of the hut in the rural areas, churches, halls and cathedrals are now institutions of solemnising marriages. The Act redefines marriage from its proper African definition to Eurocentric term referring to it as a wedding (Marriage Act Chapter 5:11:1983). Given the fact that marriage in Zimbabwe in general now refers to a 'wedding', it is evident the custom was acculturated, thereby losing its real meaning and value.

\section{Christian marriage - A misdefined and misdirecting term}

The word 'Christian marriage' has been in the historical development of marriage in the MCZ but without explaining its definition in greater detail. In 2013, the MCZ attempted to define 'Christian marriage' as a theological term but ended up offering cultural and legal definitions. Hatendi (1973) labels 'Christian marriage' as an ambiguous abstraction. Capper and Williams in their book titled Toward Christian Marriage (1958) were equally reluctant to theologically define the term. Instead, they spiritualised marriage as a rite. For them, a marriage that does not give the proper place of Jesus Christ as Lord is absolutely wrong. They add that unity in the spiritual life with combined loyalty to Jesus Christ is one of the strongest ties that can hold any couple together (Capper \& Williams 1958). This unity, however, can be possible even without a legal marriage document. As such, having a marriage certificate cannot justify the word 'Christian marriage'; neither can solemnisation of the wedding by the clergy make a marriage to be Christian nor being a Christian will make one's marriage weak.

Up to 2013, there has not been a clear theological definition of marriage by the MCZ; suffice to say that church full membership was taking into account issues of 'Christian marriage', without which it would not qualify to be confirmed as a member of the MCZ. Methodist Church in Zimbabwe took on-board civil Marriage Act 5.11 which was then Chapter 37 as 'Christian marriage'. It should be understood that the Protestant view regarded marriage as wholly civil. Martin Luther considered 
marriage not to be a church issue but rather a worldly matter for the secular authorities. Luther gave the practices of marriage to the secular leaders (Mavhuka 2014:34). The Protestants hold the view that marriage was good for procreation, child upbringing and faithfulness. They, however, rejected the sacramental view of the marriage bond as emphasised by the Roman Catholic Church. Anglicans believed that whilst the marriage rite was sacramental, marriage was never a sacrament as defined by Jesus Christ; it was not as necessary for everyone as baptism and the Eucharist (2014:34). Methodist Church's theology of marriage was influenced by the Protestant thinking because its founding fathers drank heavily from the protestant teachings and the Anglican tradition.

Upon its arrival to Zimbabwe, the Methodist Church never bothered to explain and have a sound teaching of marriage, but it followed its historical Western liturgy. The elements include the wedding ring which should be understood in the light of ancient Egyptian culture to symbolise the eternity of the pledge of fidelity by the couple (Martos 2001:381). In the solemnisation of marriages in the MCZ, the wedding veil, the tradition of the bride standing to the left of the groom and the blessing of the wedding rings as a symbols of unity and the tradition of the bride and the groom having bests as witnesses to their wedding (MCZ 2011d:59) have a western background. The tradition of the father giving his daughter in marriage hails back to the days when marriage was conceived as an exchange of property whilst that of blessing of ring and cake becomes a reinterpretation of ancient cultures that were originally not Christians (Mavhuka 2014:34). It is unfortunate that in some the MCZ marriage ceremonies, the clergy profess ignorance of the value of the parents and the groom enters the wedding venue with the bride in the absence of the father. This is one of the serious modernisation ignorance that the MCZ has to deal with because being an African church, the African concept of marriage and the role of the father in the marriage of his daughter and handing him to the groom cannot be diluted by the church's undefined and corrupted understanding of marriage.

\section{Findings}

This article revealed that adult membership in the MCZ is tied to 'Christian marriage' and yet the theology of this rite is not an independent discourse. For a long time, the church was grappling to come up with a proper theology of marriage. Whatever efforts made were characterised with coercion, intimidation and punishing of the locals to leave polygamous marriage in order to be Christians. The challenge continued unabated even after the Methodist became autonomous from the British church in 1977. Efforts to redefine Methodist mission whilst truncating marriage custom from Shona culture and civil authority were never possible, which is the problem that the MCZ finds itself in and should be redeemed from this triangular captivity. The research also finds out that Shona people process marriage rituals informed by cultural norms and values. Unfortunately, without the solemnised of the marriage by the civil authority, the MCZ does not accept it as a 'Christian marriage' supposedly mean that it is the civil procedure that Christianises marriage.
The confusion of one qualifying to be a Christian by having a civil marriage has resulted in the MCZ misguiding its members to think that all that is western is Christian and being a Christian is being Eurocentrically brainwashed. The church seems to forget that weddings are influenced by a number of factors that range from cultural, theological, sociological, political and even economic. Being accepted as a member of the church who partakes from the sacrament of the Holy Communion as a man is prestigious; however, it comes with cultural, sociological and theological complications. To some men marrying a wife is showy, whilst for others it has an economic implication whereby the company or organisation would need the marriage certificate for the spouse to be registered as a beneficiary. Unfortunately, request for weddings is seldom accepted by in-laws some of the reasons being that the in-laws feel that the son-in-law would want to spend money on 'useless things' without paying a significant amount of roora (Mujinga 2019). Some social reasons would be that the girl will be an orphan and family politics will suppress her dreams to tie the knot. As such, the MCZ has to come out of the triangular caricature and redefine its missional engagements without being influenced by either cultural or civil position of marriage.

\section{Recommendations}

Having realised the dilemma of the $\mathrm{MCZ}$ in the marriage triangular captivity, it is necessary to propose some recommendations for the church to be redeemed from this trilateral relationship. The starting point is for the MCZ to revert back to the 2013 Conference resolution that defined marriage as a monogamous union of husband and wife having been blessed by the parents through acceptance of the bride price. The Conference resolution further states that, 'the union of marriage should be followed by the Church blessings through a blessing certificate'. Soon after the marriage ritual in the family, the member can take his or her place in the church (MCZ 2013). This position leaves civil authority out of the MCZ ecclesial theology of marriage whilst embracing the role of culture because the church is a cultural entity that is defined by the culture of the environment. By emphasising this resolution, I am guided by the fact that if the MCZ is to adopt this position, it blends culture and theology together which is a biblical principle (see Gn 25) where the blessings of Laban gave Rebekah for marriage. This step deliberately leaves out the civil authority which is a different entity with nothing to do with the MCZ mission. This approach is also liberating because parental consent is equally as a blessing given to their daughter to be fruitful, whereas the government only has the legal force to keep marriages even when the two are no longer in love.

Secondly, the MCZ should emphasise marriage as a family unifier and separate the rite from a westernised way of solemnisation where couples are legally bound. This position help the MCZ to accept marriage as a lifelong union and not a union attached to the marriage certificate. This position compels the MCZ to accredit couples into its membership because marriage is a gift from God and not 
from the civil authority. Thirdly, the MCZ should also teach its members the biblical values of marriage which are not corrupted by civil authority that has a colonial mentality of punishing the locals. Fourthly, the Shona proverb murombo munhu lit. 'Even the poor is a human beings' or kuroora hakufumirwi lit. 'One does not need to get rich first in-order to marry' should define the cultural value of marriage amongst the Shona people who are members of the MCZ. This position also divorces the MCZ from civil authority's definition of marriage. This position helps grow the MCZ mission especially amongst the youths who are often victims of unplanned marriages because of the socioeconomic depletion of Zimbabwe amongst other reasons. It should, however, be cautioned that although membership has to grow, nonetheless, mission and culture should be blended together in a missio-cultural nexus of the MCZ because the two share cultural values.

Fifthly, the MCZ should align the organisational policies of the Ruwadzano/Manyano and the MCU with the main constitutions, the Deed of Church Order and Standing Orders where membership is not aligned to marriage certificates. The contradictions of the policy books compromise the theology of the MCZ. This alignment will value church membership as the mission strategy and not civil allegiance. The alignment should streamline faith of accepting Jesus as the personal saviour to be a MCZ member (MCZ 2011b) free from cultural and civil overtones. Sixthly, if the MCZ has to grow its membership from 110000 to 200000 as stipulated in the 2017-2022 Strategic Plan, the church should stop the cultural membership drive where one remains unconfirmed into membership even after paying roora. Theology must be separated from both culture and civil order. On one hand, when culture defines theology, the in-laws will be detecting when they will authorise the son-in-law to tie the knot and the mission of the church suffers. On the other hand, when civil authority defines theology, the church will be bound by a civil order which is dangerous. This recommendation is a counter to the MCZ organisation legislative instruments that tie church membership to Christian marriage enshrined in the Men Christian Union Constitution (2018), and Ruwadzano/Manyano Policy Book and Constitution (2015).

\section{Conclusion}

To conclude this article, it is evident that the MCZ is trapped between two intuitions, one cultural and the other civil which do not offer much to its missional expansion. The article argues that the MCZ needs to separate itself from culture and civil authorities and redefine itself as a missional agent of God in the Zimbabwean context. The conclusion was reached based on the fact that although the MCZ's theology is shaped by Zimbabwean milieu, its mission should neither be defined by the civil orders because these are two different kingdoms nor the membership in the church should be defined by African culture although the two share the same values. African culture and civil authority must be equal partners of the church, since their mission is different.

\section{Acknowledgements}

The author would like to thank the Methodist Church in Zimbabwe for allowing him to analyse their literature on marriage.

\section{Competing interests}

The author has declared that no competing interests exist.

\section{Author's contributions}

I declare that I am the sole author of this research article.

\section{Funding information}

This research received no specific grant from any funding agency in the public, commercial or not-forprofit sectors.

\section{Ethical consideration}

This article followed all ethical standards for a research without direct contact with human or animal subjects.

\section{Data availability statement}

Data sharing is not applicable to this article as no new data were created or analysed in this study.

\section{Disclaimer}

The views and opinions expressed in this article are those of the authors and do not necessarily reflect the official policy or position of any affiliated agency of the authors.

\section{References}

Banana, C.S., 1991, A century of Methodism in Zimbabwe, Mambo Press, Gweru.

Bhebhe, N., 1979, Christianity and traditional religion in western Zimbabwe 1859-1923, Longman, London.

Bourdillion, M.F.C., 1998, The Shona peoples an ethnography of the contemporary Shona with special reference to their religion, Mambo Press, Gweru.

British Methodist Church, 1992, The Methodist Service Book, Methodist Publishing House, Peterborough.

Capper, W.M. \& Williams, H.M., 1958, Towards Christian marriage: The privileges and responsibilities of sex, Inter-Varsity Press, Chicago, IL.

Dachs , A.J., 1973, Christianity south of the Zambezi, Mambo Press, Gweru.

Doke, C., 2005, The unification of the Shona dialects, University of Zimbabwe Allex Project, Harare.

Gelfand, M., 1968, African crucible: An ethico-religious study with special reference to the Zezuru People, Juta and Company, Cape Town.

Gondongwe, K., 2011, 'African ministers and the emergence of resistance to colonial domination: The development of indigenous clergy in the Wesleyan Methodist church in Zimbabwe', PhD thesis, University of KwaZulu-Natal, Pietermaritzburg.

Gunda, M.R., 2010, Homosexuality and the Bible in Zimbabwe, University of Bamberg Press, Bamberg.

Gunda, M.R., 2015, 'Same sex practices and relations in precolonial Zimbabwe', in E. Chitando (ed.), Engaging with the past: Same sex-relationship in pre-colonial Zimbabwe, pp. 1-12, Ecumenical HIV and AIDS Initiatives in Africa, Harare.

Hatendi, R.P., 1973, 'Shona marriage and the Christian churches', in J.A. Dachs (ed.), Christianity south of the Zambezi, pp. 135-150, Mambo Press, Gweru.

Hewitt, R.R. 2012, Church and culture: An Anglo-Caribbean experience of hybridity and contradiction, Cluster Publications, Pietermaritzburg.

Holleman, J.F., 1952, Shona customary law with reference to kinship, marriage, the family and the estate, Manchester University Press, Manchester.

Kileff, C. \& Kileff, P., 1970, Shona customs: Essays by African writers, Mambo Press, Gweru. 
Madhiba, S., 2000, Struggles and strides: A history of the localisation process of Methodism in Zimbabwe 1891-1996, Literature Department, Harare.

Magesa, L., 1997, African religion: The moral traditions of abundant life, Orbis Books, Maryknoll, New York, NY.

Mangena, F., 2015, 'Same-sex relations in precolonial Korekore-Nyombwe culture', in E. Chitando (ed.), Engaging with the past: Same sex-relationship in pre-colonia Zimbabwe, pp. 30-50, Ecumenical HIV and AIDS Initiatives in Africa, Harare.

Mangena, T. \& Ndlovu, S., 2013, 'Implications and complications of bride price payment among the Shona and Ndebele of Zimbabwe', International Journal of Asian Social Science 3(2), 472-481.

Mangwana, M.P., Mwonzora, D. \& Moyo, E., 2013, The final draft of the constitution of Republic of Zimbabwe, COPAC, Harare.

Manyoba, C.B., 1991, 'Methodist church and its response to culture', in C.S. Banana (ed.), A century of methodism, pp. 53-78, Mambo Press, Gweru.

Mapuranga, T.P., 2015, 'Same sex relations in pre-colonial Zimbabwe: A case of Manicaland Province', in E. Chitando (ed.), Engaging with the past: Same sexrelationship in pre-colonial Zimbabwe, pp. 68-82, Ecumenical HIV and AIDS Initiatives in Africa, Harare.

Martos, J., 2001, Doors to the sacred: A historical introduction to sacraments in the Catholic Church, Liguori Publishing, Liguori, MO.

Mavhuka, T., 2014, 'An African theology discourse on marriage with special focus on the Methodist church in Zimbabwe', BA Hon, Dissertation, Midlands State University, Gweru.

Mawere, M. \& Mawere, A.M., 2010, 'The changing philosophy of African marriage: The relevance of the Shona customary marriage practice of kukumbira', Journal of African Studies and Development 2(9), 224-233.

Meekers, D., 1993, 'The noble custom of roora: The marriage practices of the Shona of Zimbabwe', Ethnology 32(1), 35-54. https://doi.org/10.2307/3773544

Methodist Church in Zimbabwe, 1997, Deed of the church order and standing orders, Literature Department, Harare.

Methodist Church in Zimbabwe, 2006, Minutes of conference of the Methodist Church in Zimbabwe, Mkoba Teachers' College, Gweru.

Methodist Church in Zimbabwe, 2008, Minutes of conference of the Methodist Church in Zimbabwe, Masvingo Teachers' College, Masvingo.

Methodist Church in Zimbabwe, 2011a, Agenda of conference of the Methodist Church in Zimbabwe, Tatenda Lodges, Victoria Falls.

Methodist Church in Zimbabwe, 2011b, Deed of the church order and standing orders, Connexional Bookshop, Harare.

Methodist Church in Zimbabwe, 2011c, Minutes of conference of the Methodist Church in Zimbabwe, Tatenda Lodges, Victoria Falls.

Methodist Church in Zimbabwe, 2011d, Nziyo dzeMethodist neMinamato, Connexional Bookshop, Harare.

Methodist Church in Zimbabwe, 2013, Minutes of conference of the Methodist Church in Zimbabwe, Hillside Teachers' College, Bulawayo.

Methodist Church in Zimbabwe, 2015, Ruwadzano/Manyano Administration Policy and Constitution, Connexional Bookshop, Harare.
Methodist Church in Zimbabwe, 2018, Men's Christian Union Constitution Connexional Bookshop, Harare.

Methodist Church in Zimbabwe, 2019, Agenda of conference of the Methodist Church in Zimbabwe, Hillside Teachers' College, Bulawayo.

Mujinga, M., 2017, The historical development of Methodism: A north-south paradigm, Connexional Books shop, Harare.

Mujinga, M., 2019, 'An interrogation of the effects of the interface of Zezuru marriage custom with modernity', Conference paper, University of Zimbabwe, Harare.

Mwandayi, C., 2017, 'Towards a reform of the Christian understanding of Shona traditional marriages in light of ancient Israelite marriages', Studia Historiae Ecclesiasticae 43(3), 1-26. https://doi.org/10.17159/2412-4265/2717

Ngundu, O.A., 2011, 'Mission churches and African customary marriage: A history of church marriages and a case for an African Christian customary marriage ceremony', Africa Journal of Evangelical Theology 30(1), 35-53.

Obbo, C., 1980, African women: Their struggle for economic independence, Zed Press, London.

Richardson, A. \& Bowden, J., 1983, A new dictionary of Christian theology, SCM Press, London.

Shoko, T., 2007, Karanga indigenous religion in Zimbabwe health and well-being, Ashgate Publishing Company, Hampshire.

Shoko, T., 2015, 'Same-sex relationships among the karanga of Mberengwa in precolonial Zimbabwe', in E. Chitando (ed.), Engaging with the past: Same sexrelationship in pre-colonial Zimbabwe, pp. 29-46, Ecumenical HIV and AIDS Initiatives in Africa, Harare.

Shorter, A., 1998, African culture: An overview, Paulines Publications Africa, Nairobi.

Snyder, H., 2019, 'Literature review as a research methodology: An overview and guidelines', Journal of Business Research 104, 333-339. https://doi.org/10.1016/ j.jbusres.2019.07.039

Taringa, N., 2015, 'Same sex relations in Shona traditional society: Exploring the myth of traditional Shona sexual exceptionalism with reference to the Karanga Duma of Bikita', in E. Chitando (ed.), Engaging with the past: Same sex-relationship in precolonial Zimbabwe, pp. 13-28, Ecumenical HIV and AIDS Initiatives in Africa, Harare.

Webster, J. \& Watson, R.T., 2002, 'Analysing the past to prepare for the future: Writin a literature review', Management Information Systems Quarterly 2(26), xv-xxiii.

West, G., 2016, 'Christianity and controversies over homosexuality in contemporary Africa', in E. Chitando \& A. Van Klinken (eds.), Reconfiguring a Biblical story (Genesis 19) in the context of South African discussions about homosexuality, pp. 184-198, Routledge, Abingdon.

Zimbabwe Legal Information Institute, 1983, Marriage act [chapter 5:11], viewed 19 October 2018, from https://zimlii.org/zw/legislation/act/1964/81.

ZIMLII, 2013, Constitution of Zimbabwe Amendment (No. 20) Act, Fidelity Printres and Refiners, Harare.

Zvobgo, C., 1991, The Wesleyan Methodist missions in Zimbabwe, Longman, Harare.

Zvobgo, C., 1996, A history of the Christian mission in Zimbabwe, Mambo Press, Gweru. 